\title{
PENYELENGGARAAN MAKANAN DAN TINGKAT KEPUASAN KONSUMEN DI KANTIN ZEA MAYS INSTITUT PERTANIAN BOGOR
}

\author{
(Food Service and the Customer Satisfaction in the Cafetaria Zea Mays \\ at Bogor Agricultural University )
}

\author{
Arnati Wulansari ${ }^{1 *}$, Budi Setiawan ${ }^{1}$, dan Tiurma Sinaga ${ }^{1}$ \\ ${ }^{1}$ Departemen Gizi Masyarakat, Fakultas Ekologi Manusia (FEMA), Institut Pertanian Bogor, Bogor 16680
}

\begin{abstract}
This research aimed was to know food service and level of customer satisfaction in the Zea Mays cafetaria at Bogor Agricultural University. Case study and descriptive analysis were applied in this study. Sampling method of purposive sampling was carried out and number of subjects used was 95 people. The food service in the Zea Mays cafetaria consists of planning, purchasing, receiving, storing, processing, and distributing. The result of analysis based on Importance Performance Analysis showed that the most important attribute was the security and hygiene product and the highest performance levels was the cleanliness of dining room. More than fifty percent subjects was concerned against nutrient content of the menu (50.5\%). Based on the Customer Satisfaction Index the satisfaction value was 69.3 (satisfied). There was a correlation between job and education level with quality of the product and between income with nutrient content $(p<0.05)$.
\end{abstract}

Keywords: customer, food service, satisfaction

\begin{abstract}
ABSTRAK
Penelitian ini bertujuan untuk mengetahui penyelenggaraan makanan dan tingkat kepuasan konsumen di Kantin Zea Mays Institut Pertanian Bogor. Penelitian ini menggunakan metode penelitian analisis deskriptif dan studi kasus. Metode penarikan subjek dilakukan secara purposive dan sebanyak 95 subjek digunakan dalam penelitian ini. Penyelenggaraan makanan di Kantin Zea Mays terdiri dari perencanaan, pembelian, penerimaan, penyimpanan, pengolahan, dan penyajian. Berdasarkan hasil analisis Importance Performance Analysis (IPA) diketahui bahwa atribut yang dirasakan paling penting adalah keamanan dan kebersihan produk sedangkan atribut tingkat kinerja yang paling tinggi skornya adalah kebersihan tempat makan. Lebih dari separuh subjek masih memerhatikan kandungan gizi menu (50.5\%). Berdasarkan Customer Satisfaction Index (CSI) diperoleh nilai kepuasan sebesar 69.3 (puas). Terdapat hubungan antara pekerjaan dan tingkat pendidikan dengan penilaian atribut mutu produk dan antara pendapatan dengan penilaian terhadap atribut kandungan gizi menu $(p<0.05)$.
\end{abstract}

Kata kunci: kepuasan, konsumen, penyelenggaraan makanan

"Korespondensi: Departemen Gizi Masyarakat, Fakultas Ekologi Manusia (FEMA), Institut Pertanian Bogor, Bogor 16680. Email: arnatiwulansari@rocketmail.com 


\section{PENDAHULUAN}

Banyaknya industri jasa makanan dan gizi yang berkembang menyebabkan adanya persaingan untuk dapat memenuhi kebutuhan masyarakat (konsumen) agar memperoleh kepuasan, termasuk dalam hal melakukan penyelenggaraan makanan baik komersial maupun non komersial. Penyelenggaraan makanan adalah rangkaian kegiatan mulai dari perencanaan menu sampai dengan pendistribusian makanan kepada konsumen dalam rangka pencapaian status kesehatan yang optimal melalui pemberian makanan yang tepat dan termasuk kegiatan pencatatan, pelaporan, dan evaluasi (Depkes 2013). Salah satu contoh penyelenggaraan makanan institusi adalah kantin universitas (kampus). Menurut Palacio dan Theis (2009) tujuan utama penyelenggaraan makanan adalah menyajikan makanan agar konsumen merasa puas.

Semakin banyaknya pembeli yang rasional, suatu perusahaan hanya dapat menang dengan menciptakan dan memberikan nilai yang unggul. Selain itu, perusahaan harus mampu meningkatkan nilai dari produk, jasa, dan mengetahui tingkat kepuasan pelanggannya (Sukardi \& Chandrawatisma 2008). Pemahaman atas kepuasan pelanggan dapat memenuhi harapan konsumen. Kepuasan pelanggan sangat memengaruhi keputusan untuk melakukan suatu pembelian kembali suatu produk (Oktaviani \& Suryana 2005). Menurut Tjahyadi (2006) kepuasan konsumen merupakan titik awal tumbuhnya loyalitas pelanggan sehingga penting untuk mengetahui penilaian terhadap kepuasan konsumen. Berdasarkan uraian tersebut dapat menunjukkan bahwa pentingnya penyelenggaraan makanan yang diterapkan oleh suatu institusi yang dapat memuaskan konsumen baik dari segi kualitas maupun kuantitasnya.

Tujuan penelitian ini adalah 1) mengidentifikasi penyelenggaraan makanan di kantin Zea Mays IPB; 2) mengidentifikasi karakteristik subjek; 3) mengidentifikasi tingkat kepentingan dan tingkat kinerja pelayanan terhadap atribut mutu produk, mutu pelayanan, dan atribut kandungan gizi menu; 4) mengidentifikasi tingkat kepuasan konsumen dengan Importance Performance Analysis (IPA) dan Customer Satisfaction Index (CSI); dan 5) menganalisis hubungan karakteristik subjek terhadap atribut mutu produk, mutu pelayanan, dan kandungan gizi menu.

\section{METODE}

\section{Desain, Tempat, dan Waktu}

Penelitian ini menggunakan analisis deskriptif dan studi kasus untuk menilai tingkat kepuasan konsumen. Pengumpulan data dilaksanakan di kantin Zea Mays Institut Pertanian Bogor selama bulan April hingga Mei 2013. Pemilihan tempat dilakukan secara purposive dengan mempertimbangkan lokasi yang merupakan kantin yang bersifat non komersial dan berorientasi pada pelayanan, kemudahan perizinan, dan populasi yang memenuhi kriteria penelitian.

\section{Jumlah dan Cara Pengambilan Subjek}

Sistem pengambilan subjek ditetapkan secara purposive. Subjek yang digunakan dalam penelitian ini adalah 95 orang dengan kriteria subjek merupakan konsumen yang pernah mengunjungi atau mengonsumsi menu makanan dan minuman di kantin Zea Mays dengan frekuensi lebih dari empat kali kunjungan dan bersedia mengisi kuesioner dengan lengkap.

\section{Jenis dan Cara Pengumpulan Data}

Jenis data yang dikumpulkan yaitu data primer dan data sekunder. Data primer ini meliputi karakteristik subjek, penyelenggaraan makanan yang diterapkan, higiene dan sanitasi kantin, dan tingkat kepuasan konsumen kantin. Data sekunder meliputi data gambaran umum mengenai kantin Zea Mays IPB. Data tersebut diperoleh dengan kuesioner, wawancara, dan pengamatan langsung.

\section{Pengolahan dan Analisis Data}

Analisis yang digunakan dalam penelitian ini adalah analisis deskriptif dan analisis inferensia. Analisis deskriptif digunakan untuk menggambarkan karakteristik subjek, penyelenggaraan makanan yang diterapkan kantin, higiene dan sanitasi kantin, dan tingkat kepuasan konsumen. Higiene dan sanitasi kantin dinilai berdasarkan penilaian laik higiene dan sanitasi berdasarkan Keputusan Menteri Kesehatan RI Nomor 1098/Menkes/SK/VII/2003.

Data tingkat kepuasan dianalisis dengan menggunakan metode IPA dan CSI. Pengukuran metode IPA dilakukan pada 16 macam atribut dimana atribut tersebut dijabarkan di dalam diagram kartesius. Sumbu $X$ merupakan nilai rataan tingkat kinerja dan sumbu $Y$ merupakan nilai rataan kepentingan. Kedua sumbu tersebut membentuk dua garis tegak lurus yang saling berpotongan pada koordinat titik $(3.5 ; 4.4)$ yang membagi diagram tersebut menjadi empat kuadran.

Untuk mengetahui secara jelas penempatan 16 atribut yang telah dianalisis, maka keseluruhan atribut tersebut dikelompokkan dalam 4 kuadran. Posisi masing-masing atribut pada keempat kuadran tersebut dijadikan alat bantu dalam memberikan alternatif strategi untuk meningkatkan kepuasan konsumen.

Analisis inferensia digunakan untuk melihat hubungan antar variabel. Hubungan antara karakteristik subjek terhadap penilaian mutu produk, mutu pelayanan, dan atribut kandungan gizi menu dianalisis dengan uji korelasi Spearman sebagai uji signifikansi dengan mencari nilai $p$-value $(p<0.05)$. 


\section{HASIL DAN PEMBAHASAN}

\section{Penyelenggaraan Makanan}

Perencanaan. Penyelenggaraan makanan yang dilakukan di Kantin Zea Mays tidak dimulai dengan perencanaan menu sehingga siklus menu tidak ada. Namun kantin tetap menyelenggarakan perencanaan anggaran. Nurdianty et al. (2012) menyatakan bahwa dalam tahap perencanaan penyelenggaraan makanan, perlu dilakukan perencanaan menu dan perencanaan anggaran agar menghasilkan output yang maksimal bagi konsumen dan penyelenggara.

Pelaksanaan. Tahap pelaksanaan yang terdiri dari pembelian, penerimaan, penyimpanan, pengolahan, dan penyajian. Pembelian bahan makanan oleh pihak kantin dilakukan di pasar tradisional setiap satu minggu sekali untuk membeli sayursayuran, buah-buahan, bumbu-bumbu, serta lauk nabati dan untuk pembelian lauk hewani yaitu daging sapi, ikan, ayam, dan lauk hewani lainnya dipesan kepada rekanan yang telah dipercaya oleh pihak kantin dan dilakukan setiap 2-3 hari sekali.

Penerimaan bahan makanan dilakukan pada pagi hari (pukul 06.00 WIB) namun tidak dilakukan penimbangan ulang untuk menyesuaikan berat bahan makanan yang tersedia dengan berat bahan makanan yang dipesan. Menurut Kwon et al. (2012) penerimaan bahan makanan dalam penyelenggaraan makanan dilakukan untuk memastikan bahwa pangan diterima dalam keadaan segar dan aman sehingga bahan pangan dapat dipindahkan ke tempat yang tepat sesuai dengan karakteristik bahan pangan tersebut. Tempat penyimpanan bahan makanan dilakukan pada lemari es dan chiller yang dapat otomatis suhunya sesuai dengan bahan pangan yang disimpan. Kantin Zea Mays menerapkan prinsip FIFO (First In First Out) dengan tujuan agar bahan makanan yang telah lama disimpan dapat digunakan terlebih dahulu (Nurdianty et al.2012).

Kegiatan pengolahan dilakukan pada pagi hari (pukul 06.00 WIB). Pada saat pengolahan, penjamah makanan tidak menggunakan masker, penutup kepala, dan sarung tangan. Namun pada saat pengolahan, penjamah makanan selalu mencuci tangan sebelum melakukan pengolahan terhadap bahan makanan yang akan diolah. Menurut Damayanthi et al. (2008) tingkat pencemaran bakteri dan mikroba tinggi terhadap alat makan maupun makanan yang disajikan secara terbuka. Maka dari itu diperlukan peningkatan perilaku higiene bagi penjamah makanan. Salah satu cara dalam melakukan perilaku higiene bagi penjamah makanan yaitu dengan mencuci tangan sebelum melakukan aktivitas pengolahan makanan. Namun penjamah makanan harus memiliki pengetahuan mengenai perilaku higiene yang baik. Hal ini dikarenakan untuk menghindari adanya kontaminasi terhadap makanan (Benhura et al. 2012). Untuk penyajian dilakukan berdasarkan bar masing-masing, seperti pada table d'hote menu dihidangkan langsung pada buffet dan untuk ala carte menu serta minuman dibuat dan dihidangkan saat konsumen memesan makanan dan minuman.

Berdasarkan hasil penilaian penyelenggaraan makanan dengan menggunakan KEPMENKES nomor 1098/Menkes/SK/VII/2003 yang terdiri dari 33 variabel yaitu lokasi, bangunan, pembagian ruang, lantai, dinding, ventilasi, pencahayaan/penerangan, atap, langit-langit, pintu, air bersih, pembuangan air limbah, toilet, tempat sampah, tempat cuci tangan, tempat mencuci peralatan, tempat mencuci bahan makanan, loker pekerja, peralatan pencegah masuknya serangga dan tikus, dapur, ruang makan, gudang bahan makanan, bahan makanan, makanan jadi, proses pengolahan, penyimpanan bahan makanan, ruang makan, cara penyajian, ketentuan peralatan, pengetahuan/sertifikat higiene sanitasi makanan, pakaian kerja, pemeriksaan kesehatan, dan higiene individu. Setelah dilakukan penilaian terhadap higiene dan sanitasi diperoleh skor 802 . Total skor sebesar 802 berada dalam kisaran skor 801-900. Artinya Kantin Zea Mays secara umum laik higiene dan sanitasi dengan tingkat mutu $B$ berdasarkan KEPMENKES Nomor 1098/Menkes/SK/VII/2003.

\section{Karakteristik Subjek}

Usia. Karakteristik usia dibagi ke dalam empat kategori, yaitu usia <20 tahun, 20-30 tahun, 31-40 tahun dan $\geq 41$ tahun. Lebih dari sebagian subjek pada kantin Zea Mays berusia 20-30 tahun (71.6\%). Pada penelitian Yulianti dan Widyawati (2005) dengan subjek konsumen kantin menyatakan bahwa sebagian besar subjek yang sering mengunjungi kantin adalah pada rentang usia 20-30 tahun. Hal ini dikarenakan lokasi kantin yang terletak di kampus sehingga rata-rata konsumen yang berkunjung adalah mahasiswa dengan rentang usia 20-30 tahun.

Jenis kelamin. Lebih dari setengah subjek pada kantin Zea Mays berjenis kelamin wanita (58.9\%). Hal ini sesuai dengan data jumlah mahasiswa IPB secara keseluruhan menyatakan bahwa proporsi jumlah mahasiswi (60.2\%) lebih besar daripada proporsi mahasiswa (39.8\%). Lebih banyak mahasiswi yang memilih kantin sebagai tempat makan paling nyaman untuk memuaskan kebutuhan biologis dan berkumpul bersama teman-teman (Yuliawati \& Widyawati 2005).

Asal daerah. Hasil penelitian menunjukkan bahwa lebih dari setengah subjek pada kantin Zea Mays berasal dari pulau Jawa (52.6\%). Hal ini dikarenakan kampus IPB berada di wilayah pulau Jawa khususnya Jawa Barat sehingga banyak mahasiswa yang berasal dari daerah tersebut. Menurut penelitian Saufika et al. (2012) dengan subjek adalah mahasiswa IPB dengan persentase terbesar berasal dari 
Pulau Jawa. Subjek pada penelitian ini berasal dari beragam daerah yang juga memiliki beragam selera terhadap atribut tertentu yang berhubungan dengan mutu produk yaitu selera konsumen terhadap menu yang disajikan tentu berbeda menurut penilaian konsumen dengan asal daerah yang berbeda.

Pendidikan. Karakteristik pendidikan subjek dibagi ke dalam enam kategori yaitu SD, SLTP, SLTA, diploma, sarjana, dan pascasarjana. Hasil menunjukkan sebagian besar subjek pada kantin Zea Mays adalah sarjana (50.5\%). Hal ini dikarenakan sebagian besar pengunjung berlatar belakang pendidikan sarjana adalah mahasiswa yang sedang melakukan studi pascasarjana dan kantin ini berada pada lingkungan kampus yang sebagian besar konsumen adalah mahasiswa. Disamping itu juga, hal ini berkaitan dengan lokasi kantin yang berada pada lingkungan akademisi sehingga konsumen yang berkunjung sebagian besar adalah akademisi.

Pekerjaan. Karakteristik pekerjaan subjek dibagi ke dalam tujuh kategori, yaitu mahasiswa, asisten dosen, auditor, dosen, peneliti, pegawai swasta, dan wiraswasta. Kategori mahasiswa dibedakan menjadi mahasiswa S1, S2, dan S3. Hasil menunjukkan bahwa sebagian besar subjek adalah mahasiswa (65.3\%). Hal ini disebabkan oleh lokasi kantin yang terletak di lingkungan akademisi sehingga sebagian besar konsumen yang berkunjung ke kantin adalah mahasiswa yang ruangan kuliahnya berdekatan dengan letak kantin.

Pendapatan. Karakteristik pendapatan subjek per bulan dibagi ke dalam lima kategori yaitu pendapatan $<1$ juta rupiah, $1-<2$ juta rupiah, $2-<3$ juta rupiah, $3-<4$ juta rupiah dan $\geq 4$ juta rupiah. Hasil menunjukkan bahwa sebagian besar subjek memiliki pendapatan 1-<2 Juta rupiah (33.7\%). Hal ini dikarenakan sebagian besar subjek adalah mahasiswa yang masih dibiayai oleh orang tua sehingga mereka masih belum memiliki pendapatan tetap per bulannya.

Status pernikahan. Lebih dari setengah subjek pada kantin Zea Mays belum menikah (68.4\%). Dikarenakan sebagian besar pengunjung kantin Zea Mays adalah mahasiswa yang belum menikah dan waktunya banyak dihabiskan di kampus sehingga memilih makan di kantin kampus.

\section{Tingkat Kepentingan Mutu Produk, Mutu Pelayanan, dan Atribut Kandungan Gizi Menu}

Tingkat kepentingan konsumen terhadap mutu produk, mutu pelayanan, dan kandungan gizi menu disajikan pada Tabel 1. Hasil analisis menunjukkan bahwa atribut yang paling penting (dengan skor tertinggi yaitu 457) dirasakan adalah keamanan dan kebersihan dari makanan dan minuman yang disajikan. Hal ini berhubungan dengan keamanan pangan, apabila keamanan pangan pada tempat makan tersebut buruk maka akan menimbulkan penyakit tertentu seperti diare, sakit perut, dan lain-lain. Selain itu, sebagian besar pengunjung kantin adalah mahasiswa atau akademisi, maka hal yang menjadi pertimbangan dalam pemilihan tempat makan adalah kebersihan dan keamanan dari makanan dan minuman yang akan dikonsumsi. Sementara itu atribut dengan ratarata paling rendah (dengan skor terendah yaitu 373) adalah atribut ukuran dan bentuk potongan produk yang disajikan. Berdasarkan penilaian konsumen, ukuran dan bentuk potongan hidangan produk tidak terlalu menjadi hal dasar dalam pemilihan tempat makan. Menurut subjek, atribut ukuran dan bentuk

Tabel 1. Tingkat Kepentingan Konsumen pada Masing-masing Atribut

\begin{tabular}{clcc}
\hline No & \multicolumn{1}{c}{ Pertanyaan } & Tingkat Kepentingan & Keterangan \\
\hline 1 & Cita rasa makanan dan minuman yang disajikan & 437 & Sangat penting \\
2 & Kesesuaian harga makanan dan minuman & 416 & Sangat penting \\
3 & Keamanan dan kebersihan dari makanan dan minuman yang disajikan & 457 & Sangat penting \\
4 & Kesesuaian menu dengan selera & 417 & Sangat penting \\
5 & Variasi menu yang ditawarkan & 408 & Sangat penting \\
6 & Kesesuaian porsi makanan/minuman & 392 & Penting \\
7 & Ukuran dan bentuk potongan hidangan makanan & 373 & Penting \\
8 & Kecepatan tanggapan pramusaji terhadap keluhan pelanggan & 416 & Sangat penting \\
9 & Tersedianya makanan dan minuman yang tertera pada daftar menu & 405 & Sangat penting \\
10 & Fasilitas (sanitary kit) & 420 & Sangat penting \\
11 & Penataan eskterior dan interior ruangan & 379 & Penting \\
12 & Keramahan pelayanan & 438 & Sangat penting \\
13 & Suasana kantin & 427 & Sangat penting \\
14 & Kebersihan ruangan dan tempat makan & 449 & Sangat penting \\
15 & Kemudahan proses pembayaran & 391 & Penting \\
16 & Mengetahui kandungan gizi menu bagi konsumen & 389 & Penting \\
\hline
\end{tabular}


potongan makanan maupun minuman yang disajikan terkadang diabaikan oleh konsumen. Hal ini disebabkan sebagian besar konsumen lebih mementingkan kepuasan dalam memenuhi kebutuhan biologis saja di samping untuk menjaga kesehatan tubuh melalui makanan dan minuman yang dikonsumsi.

Tingkat Kinerja Kantin terhadap Mutu Produk, Mutu Pelayanan, dan Atribut Kandungan Gizi Menu

Atribut yang paling dinyatakan sangat puas (dengan skor tertinggi yaitu 389) adalah kebersihan tempat makan. Hal ini terlihat dari nilai rataan yang berada pada urutan tertinggi. Atribut ini juga menjadi dasar bagi pengunjung dalam memilih tempat makan yang tentunya tidak membahayakan (kotor). Sementara itu atribut yang dinilai tingkat kinerjanya paling rendah (dengan skor terendah yaitu 283) adalah atribut daftar menu produk yang tersedia. Dalam penelitian ini, subjek menyatakan bahwa daftar menu makanan dan minuman yang tersedia sehari-hari cukup penting untuk diterapkan dan ditampilkan. Apabila daftar menu tidak ada atau pada kantin ini banyak menu yang terdapat pada daftar menu namun tidak tersedia, hal ini membuat konsumen kebingungan dalam memilih jenis menu untuk dikonsumsi terlebih lagi untuk pengunjung yang baru pertama kali mengunjungi kantin tersebut. Dalam menilai tingkat kinerja pelayanan, konsumen membandingkan antara harapan yang diinginkan konsumen terhadap pelaksanaan atau kinerja aktual yang dilakukan terhadap masing-masing atributatribut yang diuji (Musanto 2004). Menurut Limbong et al. (2010), faktor yang berpengaruh dominan terhadap kepuasan pelanggan adalah kinerja, tetapi mutu pelayanan dan kinerja berpengaruh terhadap kepuasan pelanggan. Tingkat kinerja pelayanan kantin terhadap mutu produk, mutu pelayanan, dan kandungan gizi menu disajikan pada Tabel 2 .

Konsumen yang mengunjungi kantin memiliki beragam profesi namun didominasi oleh civitas akademika yang cukup perhatian terhadap kandungan gizi menu. Sebagian besar subjek masih memerhatikan label kandungan gizi pada menu (50.5\%). Subjek beranggapan bahwa hal ini dapat menjadi salah satu keunggulan dari kantin Zea Mays dan konsumen mendapatkan pengetahuan mengenai kandungan gizi pada makanan dan minuman yang mereka konsumsi. Hanya $44.2 \%$ subjek menyatakan tidak perhatian atau tidak penting mengenai pelabelan kandungan gizi pada menu dan sisanya $5.3 \%$ subjek menjawab tidak tahu. Selain itu juga dengan adanya kandungan gizi dapat memengaruhi mereka dalam memilih menu sesuai dengan kebutuhan gizi.

\section{Tingkat Kepuasan Konsumen}

IPA (Importance Performance Analysis). Gambar 1 menunjukkan hubungan tingkat kepentingan masing-masing atribut penentu kepuasan konsumen terhadap kinerjanya ke dalam diagram kartesius. Atribut-atribut yang termasuk ke dalam kuadran A merupakan atribut-atribut yang dianggap sangat penting oleh konsumen, tetapi pihak kantin belum melaksanakannya sesuai dengan keinginan konsumen. Atribut pada kuadran ini harus mendapatkan perhatian (prioritas utama dalam perbaikan) agar tingkat kepuasan konsumen bisa meningkat. Menurut hasil penelitian Elu (2005) keputusan untuk melakukan tindakan perbaikan yang sistematis merupakan payung yang dapat menentukan dalam

Tabel 2. Tingkat Kinerja Konsumen pada Masing-masing Atribut

\begin{tabular}{clcl}
\hline No & \multicolumn{1}{c}{ Pertanyaan } & Tingkat Kinerja & Keterangan \\
\hline 1 & Cita rasa makanan dan minuman yang disajikan & 327 & Puas \\
2 & Kesesuaian harga makanan dan minuman & 312 & Cukup puas \\
3 & Keamanan dan kebersihan dari makanan dan minuman yang disajikan & 375 & Puas \\
4 & Kesesuaian menu dengan selera & 321 & Cukup puas \\
5 & Variasi menu yang ditawarkan & 299 & Cukup puas \\
6 & Kesesuaian porsi makanan/minuman & 324 & Cukup puas \\
7 & Ukuran dan bentuk potongan hidangan makanan & 313 & Cukup puas \\
8 & Kecepatan tanggapan pramusaji terhadap keluhan pelanggan & 332 & Puas \\
9 & Tersedianya makanan dan minuman pada daftar menu & 283 & Cukup puas \\
10 & Fasilitas (sanitary kit) & 332 & Puas \\
11 & Penataan eskterior dan interior ruangan & 349 & Puas \\
12 & Keramahan pelayanan & 311 & Cukup puas \\
13 & Suasana kantin & 354 & Puas \\
14 & Kebersihan ruangan dan tempat makan & 389 & Puas \\
15 & Kemudahan proses pembayaran & 352 & Puas \\
16 & Mengetahui kandungan gizi menu bagi konsumen & 285 & Cukup puas \\
\hline
\end{tabular}




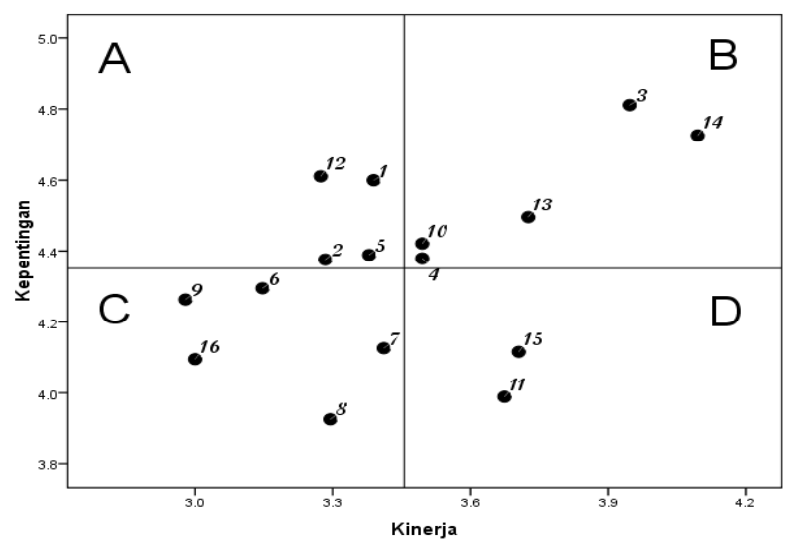

Gambar 1. Pemetaan Diagram Kartesius menjadi Kuadran A, B, C, dan D

menindaklanjuti permasalahan konsumen dari suatu kegagalan sehingga akhirnya mampu mengikat loyalitas konsumen. Atribut-atribut ini harus lebih diprioritaskan dan diperbaiki sehingga kinerja meningkat dan lebih baik lagi karena atribut ini memiliki nilai kepentingan yang tinggi bagi konsumen namun kinerjanya masih kurang memuaskan. Atribut-atribut yang termasuk ke dalam kuadran pertama adalah (1) cita rasa makanan dan minuman (faktor yang sangat penting bagi konsumen dalam memilih makanan ataupun tempat makan), (2) kesesuaian harga, (5) kesesuaian menu dengan selera konsumen, dan (12) keramahan pelayanan.

Harga produk di kantin Zea Mays bagi mahasiswa masih terlalu mahal. Hal ini dikarenakan sebagian besar konsumen atau pengunjung kantin adalah civitas akademika, namun bagi profesi lainnya tidak menjadi masalah. Atribut lainnya yang dianggap kurang memuaskan adalah kesesuaian menu dengan selera konsumen. Hal ini disebabkan karena tidak adanya siklus menu yang diterapkan di kantin tersebut. Atribut ini juga dinilai subjektif oleh konsumen dan juga berhubungan dengan cita rasa makanan dan minuman yang disajikan dan berhubungan dengan karakteristik konsumen (asal daerah). Selain itu, atribut keramahan pelayanan turut menjadi salah satu prioritas utama perbaikan pada kantin ini. Keramahan pelayanan dalam melayani konsumen dapat memengaruhi tingkat kepuasan konsumen. Atribut ini dirasakan penting oleh konsumen. Menurut hasil penelitian Raharjani (2005) kepuasan pelanggan dapat dicapai apabila konsumen merasa semua kebutuhannya terpenuhi dan mendapatkan pelayanan yang dirasa konsumen baik. Hasil penelitian ini juga konsisten terhadap hasil penelitian Mandasari dan Tama (2011) yang menyatakan bahwa perilaku staf diantaranya keramahan pelayanan merupakan atribut yang paling berpengaruh terhadap kepuasan konsumen. Oleh karena itu keramahan pelayanan kantin harus ditingkatkan lagi agar kepuasan konsumen dapat meningkat.
Atribut-atribut yang termasuk ke dalam kuadran B merupakan atribut-atribut yang dianggap penting oleh konsumen dan kinerja kantin juga sudah sangat baik. Atribut-atribut yang termasuk pada kuadran dua ini adalah (3) keamanan dan kebersihan dari makanan dan minuman yang disajikan, (4) kecepatan tanggapan pramusaji terhadap keluhan pelanggan, (10) fasilitas sanitary kit, (13) suasana kantin, dan (14) kebersihan ruangan dan tempat makan.

Peningkatan atau perbaikan pada atributatribut dalam kuadran $C$ dapat dipertimbangkan kembali oleh pihak kantin karena pengaruh terhadap manfaat yang dirasakan oleh konsumen sangat kecil. Atribut-atribut yang termasuk pada kuadran ini adalah (6) variasi menu yang ditawarkan, (7) kesesuaian porsi makanan/minuman, (8) ukuran dan bentuk potongan hidangan makanan, (9) tersedianya daftar menu, (16) mengetahui kandungan gizi menu.

Kuadran D menunjukkan tingkat kepentingan suatu atribut yang dinilai rendah, namun pelaksanaan aktual atau kinerjanya berlebihan. Dengan demikian pihak kantin dapat mengurangi biaya pada atribut dalam kuadran ini dan mengalokasikannya untuk atribut yang membutuhkan perbaikan kinerja seperti pada kuadran A. Sebaiknya kinerja pada atribut yang terdapat dalam kuadran ini dapat dipertahankan dan dapat menjadi keunggulan kantin. Atribut-atribut yang terdapat pada kuadran ini adalah (11) penataan eksterior dan interior ruangan serta (15) kemudahan proses pembayaran.

\section{Customer Satisfaction Index (CSI)}

Nilai rata-rata pada tingkat kepentingan dan tingkat kinerja dari masing-masing atribut mutu produk dan mutu pelayanan digunakan untuk menghitung CSI. Hasil perhitungan CSI pada mutu produk, mutu pelayanan, dan kandungan gizi menu disajikan pada Tabel 3.

Nilai weighted average total sebesar 3.467 yang merupakan penjumlahan dari seluruh weighted score atribut-atribut. Nilai kepuasan konsumen berdasarkan analisis CSI $69.3 \%$ yang berada pada rentang skala $0.7-0.8(66-80 \%)$ yang berarti secara umum konsumen telah puas terhadap kinerja kantin Zea mays. Namun sebaiknya pihak kantin tetap harus meningkatkan kinerjanya agar nilai CSI turut meningkat hingga mendekati 100\% yaitu konsumen merasa sangat puas dan loyalitas pun terjaga.

\section{Hubungan Karakteristik Subjek terhadap Penilai- an Mutu Produk dan Pelayanan}

Berdasarkan hasil uji korelasi Spearman terdapat hubungan antara karakteristik subjek yaitu pekerjaan dan tingkat pendidikan dengan penilaian mutu produk $(\mathrm{p}<0.05)$. Semakin tinggi tingkat pendidikan maka konsumen semakin mengerti akan pentingnya mutu produk dari suatu produk yang 
Tabel 3. Tingkat Kepuasan Konsumen berdasarkan Metode Customer Satisfaction Index

\begin{tabular}{ccccc}
\hline Nomor Atribut & Rataan Tingkat Kepentingan & Weighting Factors & Rataan Tingkat Kinerja & Weighting Score \\
\hline C1 & 4.600 & 0.066 & 3.442 & 0.227 \\
C2 & 4.379 & 0.063 & 3.284 & 0.207 \\
C3 & 4.811 & 0.069 & 3.947 & 0.273 \\
C4 & 4.379 & 0.063 & 3.495 & 0.220 \\
C5 & 4.389 & 0.063 & 3.379 & 0.213 \\
C6 & 4.295 & 0.062 & 3.147 & 0.194 \\
C7 & 4.126 & 0.059 & 3.411 & 0.202 \\
C8 & 3.926 & 0.056 & 3.295 & 0.186 \\
C9 & 4.263 & 0.061 & 2.979 & 0.182 \\
C10 & 4.421 & 0.064 & 3.495 & 0.222 \\
C11 & 3.989 & 0.057 & 3.674 & 0.211 \\
C12 & 4.611 & 0.066 & 3.274 & 0.217 \\
C13 & 4.495 & 0.065 & 3.726 & 0.241 \\
C14 & 4.726 & 4.095 & 0.278 \\
C15 & 4.116 & 3.705 & 0.177 \\
C16 & 0.059 & 3.000 & 0.218 \\
\hline \multicolumn{5}{c}{ Weight Average Total } \\
\hline \multicolumn{5}{c}{ Customer Satisfaction Index } \\
\hline
\end{tabular}

akan dibeli atau dikonsumsi. Pendidikan berhubungan dengan pekerjaan. Semakin tinggi tingkat pendidikan maka semakin besar kesempatan untuk mendapatkan pekerjaan (Sumarwan 2003).

Menurut hasil penelitian Irawan dan Japarianto (2013), kualitas atau mutu produk memiliki pengaruh terhadap loyalitas pelanggan yang lebih kecil dibandingkan pengaruh kualitas produk terhadap kepuasan pelanggan. Artinya, kualitas produk memengaruhi puas atau tidaknya konsumen yang akan berdampak kepada loyalitas.

\section{Hubungan Karakteristik Subjek terhadap Penilai- an Mutu Pelayanan}

Berdasarkan hasil uji korelasi Spearman tidak terdapat hubungan antara karakteristik subjek dengan penilaian mutu pelayanan ( $p>0.05$ ). Hal ini dikarenakan penilaian mutu pelayanan didasarkan oleh pelaksanaan aktual dari pihak kantin dan tidak dipengaruhi oleh karakteristik individu seseorang. Mutu pelayanan juga tidak memengaruhi pengambilan keputusan untuk mengonsumsi atau tidak suatu produk (Lamidi 2012). Hasil penelitian Susanti et al. (2009) menyatakan bahwa hubungan antara proses pelayanan dengan tingkat kepuasan menunjukkan hubungan yang sangat nyata. Artinya semakin baik proses pelayanan maka semakin tinggi tingkat kepuasan yang dirasakan oleh konsumen.

\section{Hubungan Karakteristik Subjek terhadap Atribut Kandungan Gizi Menu \\ Berdasarkan hasil uji korelasi Spearman ter- dapat hubungan antara karakteristik subjek dengan}

atribut kandungan gizi menu $(\mathrm{p}<0.05)$. Karakteristik subjek tersebut berupa pendapatan. Semakin tinggi pendapatan maka semakin tinggi pula penilaian terhadap atribut kandungan gizi menu. Hal ini disebabkan karena adanya hubungan antara tingkat pendidikan yang dapat memengaruhi pekerjaan dan pekerjaan yang menghasilkan pendapatan (Sumarwan 2003).

\section{KESIMPULAN}

Kantin Zea Mays secara umum telah laik higiene dan sanitasi menurut Kepmenkes No 1098/ Menkes/SK/VII/2003 dengan skor 802 dan termasuk mutu B. Sebagian besar subjek adalah perempuan (59.0\%) dengan rentang usia 20-30 tahun sebanyak $72.0 \%$ dan pulau Jawa menjadi asal daerah sebagian besar subjek (53.0\%). Sebanyak $68.0 \%$ subjek belum menikah dengan pendidikan terakhir adalah sarjana (51.0\%). Uang saku sebagian besar subjek per bulan adalah sekitar Rp 1000000 hingga kurang dari Rp 2000000 (34.0\%) dengan 65.0\% adalah mahasiswa.

Atribut keamanan dan kebersihan dari ma-kanan dan minuman yang disajikan, dinilai oleh subjek sangat penting (skor 457) sedangkan untuk tingkat kinerja pelayanan pada atribut kebersihan tempat makan merupakan atribut tertinggi (skor 389). Atribut pada kuadran A yaitu cita rasa makanan dan minuman yang tersedia, harga, kesesuaian menu dengan selera konsumen, dan keramahan pelayanan harus menjadi prioritas utama pihak kantin dalam memperbaiki kinerja dalam mutu pelayanan karena konsumen masih merasa kurang puas pada kinerja 
yang diberikan oleh pihak kantin. Nilai CSI 69.3\% menunjukkan konsumen telah puas terhadap kinerja pihak kantin Zea Mays. Terdapat korelasi positif antara pekerjaan dan tingkat pendapatan dengan mutu produk dan korelasi positif antara pendapatan dengan atribut kandungan gizi menu $(\mathrm{p}<0.05)$.

\section{DAFTAR PUSTAKA}

Benhura C, Nyagura SF, Gombiro PE, Dakwa F, \& Ngeyniyama P. 2012. Food service quality survey at the University of Zimbabwe private canteens. Journal of Food Science and Technology, 4(5), 281-285.

Damayanthi E, Yuliati L, Suprapti V, \& Sari F. 2008. Aspek sanitasi dan higiene di kantin asrama Tingkat Persiapan Bersama IPB. Jurnal Gizi dan Pangan, 3(1), 22-29.

[Depkes RI] Departemen Kesehatan RI. 2013. Pedoman Pelayanan Gizi Rumah Sakit. Ditjen Bina Kesehatan Masyarakat, Jakarta.

Elu B. 2005. Manajemen penanganan komplain konsumen di industri jasa. Jurnal ilmu administrasi dan organisasi, bisnis, dan birokrasi, 13(3), 1-13.

Kwon S, Bednar CM, Junehee K, \& Butler KA. 2012. An investigation of college and university foodservice administrator's level of agreement on potensial influencing factors on sustainable food waste management. Journal of Foodservice Management and Education, 6(2), 21-26.

Lamidi. 2012. Hubungan kualitas pelayanan, harga, kepuasan, dan loyalitas. Jurnal Ekonomi dan Kewirausahaan, 12(2), 143-156.

Limbong LO, Hubeis M, \& Syamsun M. 2010. Pengaruh mutu pelayanan dan kinerja bank terhadap kepuasan nasabah Bank Danamon Cabang Bogor. Jurnal Manajemen IKM, 5(2), 166-174.

Mandasari V \& Tama BA. 2011. Analisis kepuasan konsumen terhadap restoran siap saji melalui data mining. Jurnal Manajemen dan Kewirausahaan, 6(1), 25-27.
Musanto. 2004. Faktor yang mempengaruhi loyalitas konsumen. Jurnal Manajemen dan Kewirausahaan, 6(2), 123-156.

Nurdianty, Radhiyah, Daetilan DM, \& Nawir N. 2012. Penyelenggaraan makanan dan tingkat kepuasan atlet di Pusat Pendidikan dan Latihan Pelajar Dinas Pendidikan Pemuda dan Olahraga Makassar. Media Gizi Masyarakat Indonesia, 1(2), 91-96.

Oktaviani RW \& Suryana RN. 2005. Analisis kepuasan pengunjung dan pengembangan fasilitas wisata agro. Jurnal Agro Ekonomi, 24(1), 41-58.

Palacio \& Theis. 2009. Introduction to Food Service. Pearson Education, Ohio.

Raharjani J. 2005. Analisis faktor-faktor yang memengaruhi keputusan pemilihan pasar swalayan sebagai tempat berbelanja. Jurnal studi manajemen dan organisasi, 2(1), 1-15.

Saufika, Retnaningsih, \& Alfiasari. 2012. Gaya hidup kebiasaan makan mahasiswa. Jurnal Ilmu Keluarga dan Konsumen, 5(2), 157-165.

Sukardi \& Chandrawatisma C. 2008. Analisis tingkat kepuasan pelanggan terhadap produk Corned Pronas produksi PT Cip Denpasar. Jurnal Teknik Industri Pertanian, 18(2), 106-117.

Sumarwan U. 2003. Perilaku Konsumen dan Penerapannya dalam Pemasaran. Ghalia Indonesia, Jakarta.

Susanti A, Syamsun M, \& Saleh A. 2009. Proses pelayanan dan tingkat kepuasan debitur terhadap mutu produk dan pelayanan kredit. Jurnal Manajemen Indonesia, 4(1), 38-56.

Tjahyadi. 2006. Brand trust dalam konteks loyalitas merek: peran karakteristik merek, karakteristik perusahaan dan karakteristik merek pelanggan. Jurnal Manajemen, 6(1), 65-75.

Yuliati L \& Widyawati. 2005. Respon ketidakpuasan terhadap kualitas dan pelayanan food court di Kampus IPB. Jurnal Media Gizi dan Keluarga, 29(2), 88-95. 